\title{
Sand Supplementation to Eutrophic Sediments Improves the Growth and Survival of Seagrass Thalassia Hemprichii: Implication for Seagrass Restoration and Management
}

\section{Zhijian Jiang ( $\sigma_{\text {jiangzj1982@163.com ) }}$}

South China Sea Institute of Oceanology Chinese Academy of Sciences https://orcid.org/0000-0002-8697-9613

Songlin Liu

South China Sea Institute of Oceanology Chinese Academy of Sciences

Lijun Cui

South China Sea Institute of Oceanology Chinese Academy of Sciences

Jialu He

South China Sea Institute of Oceanology Chinese Academy of Sciences

Yang Fang

South China Sea Institute of Oceanology Chinese Academy of Sciences

Chanaka Premarathne

South China Sea Institute of Oceanology Chinese Academy of Sciences

Linglan Li

South China Sea Institute of Oceanology Chinese Academy of Sciences

Yunchao Wu

South China Sea Institute of Oceanology Chinese Academy of Sciences

Xiaoping Huang

South China Sea Institute of Oceanology Chinese Academy of Sciences

Manoj Kumar

University of Technology Sydney

\section{Research Article}

Keywords: Eutrophic sediment, Sandy sediment, Seagrass, Photosynthesis, Metabolomics, Stable sulfur Isotope

Posted Date: April 19th, 2021

DOl: https://doi.org/10.21203/rs.3.rs-402780/v1

License: @ (i) This work is licensed under a Creative Commons Attribution 4.0 International License. Read Full License 


\section{Abstract}

Aims Sediment composition is highly crucial for seagrass growth and survival. Eutrophication has been suggested a major cause of seagrass decline globally. We investigated the effects of beach sand supplementation to natural sediments under eutrophic condition on the growth and survival of tropical dominant seagrass Thalassia hemprichii.

Methods We cultured seagrass $T$. hemprichii under the controlled laboratory conditions in three sediment types by combining different ratio of in-situ eutrophic sediment and coarse beach sand. We examined the effect of beach sand mixing to natural eutrophic sediments on the growth of seagrass using photobiology, metabolomics and isotope labeling approaches.

Results Seagrass grown in eutrophic sediments mixed with sand exhibited significantly higher photosynthetic activity with high relative maximum electron transport rate and minimum saturating irradiance. Simultaneously, considerably greater belowground amino acid and flavonoid concentrations were observed to counteract anoxic stress in eutrophic sediment without mixing sand. This led to more positive belowground stable sulfur isotope in the eutrophic sediment with lower Eh.

Conclusions These results indicated coarse beach sand indirectly enhanced photosynthesis and growth for $T$. hemprichii by reducing sulfide intrusion with lower concentrations of amino acid and flavonoid. This could possibly explain why $T$. hemprichii often grow better in the coarse sand substrate. Therefore, it is imperative to consider adding sand soil in the sediments to improve the growth condition for seagrass and restoring the seagrass shoots during transplantation in eutrophicated ecosystem.

\section{Introduction}

Seagrass meadows are marine ecosystem engineers and provide important ecological services including nutrient uptake, carbon sequestration, food source and habitat, shoreline and sediment stabilization (Hemminga and Duarte 2000; Larkum et al. 2006). However, global climate change and sustained pressures from coastal developments including dredging and eutrophication (nutrient enrichment) have weakened the capacity of seagrass meadows to support coastal productivity (Jiang et al. 2018; Waycott et al. 2009). Eutrophication stimulates opportunistic macro and micro algae proliferation (Burkholder et al. 2007; de Boer 2007) over the seagrass canopy and thereby reduces the light available to seagrasses below them causing shading effect. Meanwhile, algal proliferation also produced high detritus (Bishop and Kelaher 2013), modifying the origin, grain size and nutrient availability of the sediment (de Boer 2007; Liu et al. 2016). Moreover, anoxic occurred due to eutrophication and induced the sulfide intrusion in seagrasses, as assessed by stable sulfur isotope signals, leading to adverse effects as well (Holmer and Hasler-Sheetal 2014). To date, the physiological indicators have largely failed to monitor seagrass health and prevent their decline. This alarming decline highlights a global urgency to implement effective seagrass management strategies to prevent their decline.

Recently, with the influx of genomic information in seagrasses including Zostera sp. (Lee et al. 2016; Olsen et al. 2016) and Halophila stipulacea (Tsakogiannis et al. 2020), system biology based omics (transcriptomics, proteomics and metabolomics) has emerged as a new frontier in seagrass research and has deepen our understanding on their stress tolerance mechanism and to identify biomarkers of their phenotypic plasticity to environmental stress (Kumar et al. 2016; Kumar and Ralph 2017). Especially, metabolomics has been instrumental in connecting genotype and phenotype of higher plants under adverse environmental conditions and also emerging in seagrass research (Hammer et al. 2018; Hasler-Sheetal et al. 2015; Kumar et al. 2016) providing new insights on diverse cellular pathways to identify biomarkers of stress tolerance. Most of the seagrass researches were on the responses of primary metabolites (de Kock et al. 2020; Pérez et al. 2007) and the total content of key secondary metabolites to environmental stress (Arnold et al. 2014). However, little is available on the response of the composition of key secondary metabolites by applying targeted metabolomics technique.

Seagrass Thalassia hemprichii, the dominant tropical specie, distributes chiefly in sandy sediment or coral substrate (Chiu et al. 2013; Jiang et al. 2017). Over the decade, nutrient inputs into seagrass bed in Xincun Bay, Hainan Island, South China Sea, has increased immensely, leading to high eutrophication (Jiang et al. 2018). Macroalgal and epiphytes have proliferated, covering on seagrasses and contributed large detritus to the surface sediments (Liu et al. 2019). Meanwhile, cage farming and shrimp pond culture here have also produced large quantity of food debris, that has modified the sediment particle sizes (Jiang et al. 2018). Sediment particle size has decreased from coarse to fine particles. Hypoxic conditions in the sediments occurs frequently, even the emergence of red tides have been noticed in these areas (Li et al. 2010). Overall, these adverse environmental conditions have resulted in a decline of seagrass beds by decreasing the area about 50 ha (Huang et al. 2019). Interestingly, according to our continuous observation, the occurrence of T. hemprichii in Xincun Bay has declined dramatically, especially in the high intertidal zones. Moreover, we have observed a very low success rate in transplanting and restoring T. hemprichii in this bay (personal observations). The failure might be attributed to desiccation exposure during low tide, sediment composition (mud versus sand) and so on (van Katwijk and Wijgergangs 2004). Nevertheless, far fewer studies have considered the effect of sediment type on seagrass physiology (de Kock et al. 2020), especially the flavonoid, the key secondary metabolics. Furthermore, sulfation of flavonoids in seagrass might mitigate the sulfide intrusion (GrignonDubois and Rezzonico 2018), but less evidence is available.

Therefore, it is highly imperative to investigate the effect of sediment types on the physiological responses of the tropical dominant seagrass $T$. hemprichii. We undertook a laboratory manipulative experiment by growing T. hemprichii under three sediment types (by combining different ratio of in-situ eutrophic sediment and coarse beach sand) and assessed its growth performance by evaluating photosynthetic performance, profiling of flavonoid and amino acids together with stable sulfur isotope and elemental compositions. The pulse amplitude modulated fluorometry was applied, since it could accurately assess the continuous photosynthetic characteristics of seagrasses in the same leaf in a non-destructive way (Beer and Björk 2000; Ralph et al. 1998), without disturbing sediments as well. We hypothesized that 1 ) seagrass cultures in sediment with large particle size shows higher photosynthetic efficiency due to oxygenic environment and less sulfide intrusion, 2) sediment with small particle size causes hypoxic stress with accumulation of diverse flavonoids and amino acids, 3) sediment with small particle size induces higher belowground $\delta^{34} \mathrm{~S}$ due to the consumption of the sulfide intruded into seagrass by enhanced flavonoids. The results obtained in this study provide new insights that aid to understand the mechanism controlling seagrass physiological response to sediment types. This 
information is critical for strengthening the knowledge on improving successful rate for seagrass planting and transplantation in the coastal areas that are eutrophic already or in the process of eutrophication, and to implement effective seagrass management strategies to prevent their decline.

\section{Materials And Methods}

About 250 Intact shoots of healthy T. hemprichii in the same patch were collected to avoid patch difference. It's a sand-clay site with a water depth of $\sim 2 \mathrm{~m}$ in Xincun Bay $\left(18^{\circ} 24^{\prime} 34^{\prime \prime} \mathrm{N}-18^{\circ} 24^{\prime} 42^{\prime \prime} \mathrm{N}, 109^{\circ} 57^{\prime} 42^{\prime \prime} \mathrm{E}-109^{\circ} 57^{\prime} 58^{\prime \prime} \mathrm{E}\right)$ located in southeast of Hainan Island, Southern China. The seagrass density was between 208 and 340 shoots $/ \mathrm{m}^{2}$, and the biomass ratio of aboveground to belowground tissue was between 0.15 and 0.20 . Plants were collected carefully to keep belowground structures intact, and transported immediately to the laboratory in buckets with cover containing seawater. Meanwhile, 2 boxes of in-situ sediment below $T$. hemprichii and 1 box of coarse beach sand without sieving along the coastline were also collected. Plants were gently washed with in-situ seawater, separated into single shoot, and then cultured in the aquarium with in-situ seawater and sediments for $7 \mathrm{~d}$ prior to the start of the experiments. The light intensity at the surface of the seagrass leaves was $150 \mu \mathrm{mol}$ photons $\mathrm{m}^{-2} \mathrm{~s}^{-1}$, and the temperature was kept at $25^{\circ} \mathrm{C}$ using air conditioning. Light was applied with $400 \mathrm{~W}$ metal-halide lamps, and was set on a 12 hour cycle.

\section{Experimental design}

T. hemprichii was placed into 9 glass tanks $(270 \times 220 \times 250 \mathrm{~mm})$ with 20 shoots in each tank, and cultured at three sediment types with in-situ sediment combination with different ratio of coarse beach sand (Fig. 1). The sediment thickness was $8 \mathrm{~cm}$, and the overlying volume of the seawater was $8.91 \mathrm{dm}{ }^{3}$. The seawater $\mathrm{pH}$, salinity and dissolved inorganic nitrogen were $8.08 \pm 0.04,30.45 \pm 0.92,7.45 \pm 0.74 \mu \mathrm{mol} \mathrm{L} \mathrm{L}^{-1}$, respectively. The seawater was aerated without replicating tides, since the seagrasses collected was in the lower intertidal with little air exposure. 1:0 represented the in-situ sediment without combining with coarse beach sand was added in the tank; 1:1 represented the combination of half in-situ sediment and half coarse beach sand was added in the tank; $1: 2$ represented the combination of $1 / 3$ in-situ sediment and $2 / 3$ coarse beach sand was added in the tank. The sediment physiochemical parameters were showed in Table 1. The concentrations of sediment organic carbon, total nitrogen, organic matter, and sulfur under 1:0 treatment were all higher than the other two treatments, while $\delta^{34} S$ exhibited a contrast trend. For the particle size, an increased trend was observed for sand composition from 1:0, 1:1 and 1:2, while clay composition showed an inverse trend (Table 1). For the sand composition, a decrease trend was found for the coarse sand composition from 1:0, 1:1 and 1:2, while fine sand indicated a contrast trend. Plants were maintained under these conditions for $21 \mathrm{~d}$.

Table 1 Sediment physiochemical parameters

\begin{tabular}{|c|c|c|c|c|c|c|c|c|c|c|}
\hline \multirow{2}{*}{$\begin{array}{l}\text { Sediment } \\
\text { type }\end{array}$} & \multirow{2}{*}{$\mathrm{pH}$} & \multirow[t]{2}{*}{$N(\%)$} & \multirow[t]{2}{*}{ C (\%) } & \multirow{2}{*}{$\begin{array}{l}\text { Organic } \\
\text { matter } \\
(\%)\end{array}$} & \multirow[t]{2}{*}{$\mathrm{S}(\%)$} & \multirow[t]{2}{*}{$\delta^{34} S(\%)$} & \multicolumn{4}{|c|}{ Particle sizes } \\
\hline & & & & & & & $\begin{array}{l}\text { Coarse } \\
\text { sand }\end{array}$ & $\begin{array}{l}\text { Medium } \\
\text { sand }\end{array}$ & Fine sand & $\begin{array}{l}\text { Very fine } \\
\text { sand }\end{array}$ \\
\hline $1: 0$ & $8.83 \pm 0.04$ & $0.034 \pm 0.005$ & $0.344 \pm 0.059$ & $1.38 \pm 0.11$ & $0.017 \pm 0.001$ & $-0.80 \pm 0.49$ & 0.254 & 31.237 & 58.067 & 3.628 \\
\hline $1: 1$ & $8.64 \pm 0.02$ & $0.025 \pm 0.002$ & $0.253 \pm 0.029$ & $1.11 \pm 0.17$ & $0.013 \pm 0.005$ & $1.09 \pm 1.14$ & 6.274 & 44.017 & 41.076 & 3.842 \\
\hline $1: 2$ & $8.92 \pm 0.04$ & $0.020 \pm 0.003$ & $0.216 \pm 0.045$ & $0.90 \pm 0.03$ & $0.009 \pm 0.001$ & $2.60 \pm 1.19$ & 11.185 & 44.667 & 35.584 & 4.149 \\
\hline
\end{tabular}

\section{Photosynthetic performance and biochemical analysis}

A PAM fluorometer (Mini-PAM, WALZGmbH) was used to generate effective quantum yield $\left(\Phi_{P S I I}\right)$ and rapid light curves (RLCs). Photosynthetic performance was measured for the same shoot in each tank in day 6 and day 21. An effective yield measurement was taken using a saturation pulse of $0.8 \mathrm{~s}$, before the actinic light was applied ( quasi-darkness), and at the end of each 10 s irradiance step, resulting in nine $\Phi_{P S / /}$ measurements (Ralph and Gademann 2005). The RLCs was initiated by attaching a dark leaf clip to the middle part of the second innermost leaf of every shoot for reducing any within-shoot variability. Eight consecutive light levels of $88,179,328,512,729,1121,1563$ and $2400 \mu \mathrm{mol}$ photons $\mathrm{m}^{-2} \mathrm{~s}^{-1}$ were applied at $10 \mathrm{~s}$ intervals. The RLCs used a relative measure (because leaf absorbance was not directly measured) of electron transport rates (RETR) (Beer et al. 2001; Schwarz et al. 2000), calculated from following equation:

$R E T R=\Phi_{P S I I} \times P A R \times 0.5 \times A F$

Without knowledge of the actual amount of light being absorbed, fluorescence measurements can be used as an approximation of electron transport rates (Ralph et al. 1998). We used the instrument default AF value (AF=0.84) to calculate RETR, as recommended by Beer et al. (2001). The relative maximum electron transport rate $\left(\mathrm{RETR}_{\mathrm{max}}\right)$, representing photosynthetic capacity, was derived by fitting the RLCs to the double exponential decay function (Platt et al. 1980), using a least-squares non-linear curve-fitting algorithm:

$R E T R=P S\left(1-e^{-(a P A R / P s)}\right) e^{-(B P A R / P S)} \square \llbracket 2 \rrbracket$

Ps value is a scaling factor which was in turn used to calculate RETR $\max , a$ (the initial slope of the light limited relationship) and $\beta$ (down-regulation).

$\operatorname{RETR}_{\max }=P S[a /(a+\beta)][\beta /(a+\beta)](\beta / a) \bigotimes \varangle 3 \bigotimes$

And the minimum saturating irradiance $\left(E_{k}\right)$ was calculated by dividing the RETR $R_{\max }$ by the initial slope. All calculations were performed in Statistica 6.0 (Statsoft, Tulsa, Okla., USA). 
At the end of the experiment, plants were carefully retrieved and separated into aboveground and belowground tissues. Subsamples were oven-dried $\left(60^{\circ} \mathrm{C}\right)$ and individually powdered with a grinder to pass through an 80-mesh sieve (the mesh diameter was $0.18 \mathrm{~mm}$ ) for measuring nutrients and stable sulfur isotope, while the other subsamples were sent for measuring composition of free amino acids and flavonoid with dry ice. The concentrations of tissue nitrogen were determined with a CHN analyser (Elementar, Vario EL-III, Germany). Stable isotope sulfur and sulfur content were measured with DELTA V Advantage isotope mass spectrometer and EA-HT Elemental analyzer. Amino acids were measured by Waters Quattro premier XE, while flavonoids were measured by Waters ACQUITY UPLC and Triple quadrupole mass spectrometer (AB 4000).

\section{Sediment analysis}

The particle sizes of the sediment samples were analyzed using a laser diffractometer (Malvem Mastersizer 2000) capable of analyzing particle sizes between 0.02-2000 $\mu \mathrm{m}$. Grain sizes (size distribution and statistical expressions) are required to describe sediment attributes. Sand, silt and clay are end members of triangular diagrams that are divided into named textural categories depending on their apparent natural groupings (Folk et al. 1970). Grain sizes were divided into 3 groups: <4 $\mu \mathrm{m}$ (clay), 4-63 $\mu \mathrm{m}$ (silt), and $>63 \mu \mathrm{m}$ (sand) (Folk et al. 1970). The sediment samples were freeze-dried, ground and homogenized with a mortar and pestle. Half of the samples were acidified overnight with $1 \mathrm{~mol} / \mathrm{L} \mathrm{HCl}$ at room temperature to remove carbonate. The acidified samples were washed with distilled water and dried at $40{ }^{\circ} \mathrm{C}$ in an oven. All samples were stored in a desiccator prior to analysis. The concentrations of sediment organic carbon and total nitrogen were determined with a CHN analyser (Elementar, Vario EL-III, Germany). Sediment organic matter content was analyzed by sediment calcination in a muffle furnace $\left(550^{\circ} \mathrm{C}\right.$ for four hours) (Heiri et al. 2001). The pH of the sediments was measured in distilled water with a 1:2.5 sediment/solution ratio using a portable $\mathrm{pH}$ acidometer (PHB-4).

At the end of the experiment, sediment Eh was measured with an oxidation reduction potentiometer (Mettler Toledo, Seven 2 Go).

\section{Statistical analysis}

The means and standard errors of all the variables were calculated, and all the data were first tested to determine whether the assumptions of homogeneity and normality were met. Where these assumptions were not met, the raw data were transformed, and a further statistical analysis was conducted using the dataset that fulfilled the assumptions. The effect of sediment type was analyzed by one-way ANOVA using SPSS for Windows version 18. Treatment means were compared and separated by least significant difference (LSD) at $P<0.05$. Multiple comparison test that didn't assume equal variances was Dunnett's T3.

\section{Results}

\section{Sediment physiochemical parameters}

The Eh in the sediment type of 1:0, 1:1 and 1:2 were $-177.0 \pm 29.4,-148.7 \pm 24.2$ and $-53.3 \pm 17.1$, respectively, and the corresponding sediment sulfur content were $0.020 \pm 0.001,0.011 \pm 0.001$, and $0.006 \pm 0.002$, respectively (Table 2). Meanwhile, the sediment organic matter also exhibited a decreased trend along the increased sediment particle sizes.

Table 2 Sediment physiochemical parameters at the end of the experiment

\begin{tabular}{|llll|}
\hline Sediment type & Eh & $S(\%)$ & Organic matter \\
\hline $1: 0$ & $-177.0 \pm 29.4$ & $0.020 \pm 0.001$ & $1.14 \pm 0.09$ \\
\hline $1: 1$ & $-148.7 \pm 24.2$ & $0.011 \pm 0.001$ & $0.75 \pm 0.22$ \\
\hline $1: 2$ & $-53.3 \pm 17.1$ & $0.006 \pm 0.002$ & $0.58 \pm 0.04$ \\
\hline
\end{tabular}

\section{Photosynthesis}

Effects of sediment type on the photosynthetic parameters at two stages were depicted in Fig. 2. No significant difference was observed for effective quantum yield at day 6 and day 21 (at the end of the experiment) (Fig. S1). Interestingly, there was also insignificant difference for ETR $R_{\text {max }}, E_{k}, a$ (the initial slope of the light limited relationship) and $\beta$ (down-regulation) among the treatments at day 6 . However, markedly difference was found at day 21 for both ETR $\mathrm{max}_{\text {and }} \mathrm{E}_{\mathrm{k}}$ with higher value in the sediment with smaller particle size, whileaand $\beta$ exhibited a contrast trend (Fig. 2).

\section{Nitrogen and compositions of seagrass amino acids and flavonoids}

Among amino acids, proline, sarcosine and lysine were the chief three compositions in the aboveground tissue of $T$. hemprichii, while sarcosine, proline and asparagic acid were the main three compositions in the belowground tissue. Amino acids content in the aboveground tissue was lower than in belowground tissue in sediment type of 1:0, while similar concentration was observed between aboveground and belowground tissue for T. hemprichii in both sediment types of 1:1 and 1:2. Significant effects were observed for 11 kinds of the 20 amino acids in the aboveground tissue, while there were 18 kinds for the belowground tissue. Amino acid content in the both aboveground and belowground tissues in 1:0 treatments were significantly higher than those in 1:1 and 1:2 treatments. Similarly, sarcosine, proline and alanine in the both aboveground and belowground tissues also showed the same trend. The nitrogen content in the aboveground tissue was significantly higher in the larger particle sizes, while the ratio of amino acids to nitrogen in the same tissue showed a contrast trend (Fig. 3, Table 3 and Table 5). 
Among flavonoids, galuteolin, Luteolin and Isoquercitrin were the prime three compositions in the aboveground tissue of $T$. hemprichii in the three sediment types. For belowground tissue, catechinПisoquercitrin and epicatechin were the major three compositions in the sediment type of 1:0, while catechin, isoquercitrin and luteolin were the leading three compositions in the sediment type of 1:1 and 1:2. Flavonoids concentration in the aboveground tissue was lower than in belowground tissue in sediment type of 1:0 and 1:1, while similar concentration was observed between aboveground and belowground tissue for T. hemprichii in sediment type of 1:2. Flavonoids in the both aboveground and belowground tissues were higher in sediment type of $1: 0$ than of $1: 1$ and $1: 2$ (Table 4 and Table 5).

The relationships of amino acids and flavonoids in the aboveground and belowground tissues were both significantly positive (Fig. 4). Linear regression tests were performed between the concentration of total flavonoids and amino acids and the sediment sand composition. The results showed that the amino acids in the both aboveground and belowground tissues and total flavonoids in the belowground tissue were significantly negative correlated with sediment sand composition (Table 6).

\section{Content of $\delta^{34} \mathrm{~S}$}

Effects of sediment type on the $\delta^{34} \mathrm{~S}$ content in the belowground tissue of $T$. hemprichii was depicted in Fig. 5. Significant difference was observed for the $\delta^{34} \mathrm{~S}$ content, with higher value in the belowground tissue in the sediment with smaller particle size.

Table 3 Effect of sediment type on the amino acids in the aboveground and belowground tissue of Thalassia hemprichii. 1:0, the in-situ sediment without combining with coarse beach sand was added in the tank; $1: 1$, the combination of half in-situ sediment and half coarse beach sand was added in the tank; $1: 2$, the combination of $1 / 3$ in-situ sediment and $2 / 3$ coarse beach sand was added in the tank.

\begin{tabular}{|c|c|c|c|c|c|c|c|c|c|c|}
\hline \multirow[t]{3}{*}{ Amino acid } & \multicolumn{6}{|c|}{ Aboveground tissue } & \multicolumn{4}{|c|}{ Belowground tissue } \\
\hline & \multicolumn{2}{|l|}{ 1:0 } & \multicolumn{2}{|l|}{$1: 1$} & \multicolumn{2}{|l|}{$1: 2$} & \multicolumn{2}{|l|}{$1: 0$} & \multicolumn{2}{|l|}{$1: 1$} \\
\hline & $\begin{array}{l}\text { content } \\
(\mu \mathrm{g} / \mathrm{g})\end{array}$ & $\begin{array}{l}\text { ratio } \\
(\%)\end{array}$ & $\begin{array}{l}\text { content } \\
(\mu \mathrm{g} / \mathrm{g})\end{array}$ & $\begin{array}{l}\text { ratio } \\
(\%)\end{array}$ & $\begin{array}{l}\text { content } \\
(\mu \mathrm{g} / \mathrm{g})\end{array}$ & $\begin{array}{l}\text { ratio } \\
(\%)\end{array}$ & $\begin{array}{l}\text { content } \\
(\mu \mathrm{g} / \mathrm{g})\end{array}$ & $\begin{array}{l}\text { ratio } \\
(\%)\end{array}$ & $\begin{array}{l}\text { content } \\
(\mu \mathrm{g} / \mathrm{g})\end{array}$ & $\begin{array}{l}\text { ratio } \\
(\%)\end{array}$ \\
\hline glycine & $38.2 \pm 5.6^{a}$ & 0.71 & $17.9 \pm 4.2^{b}$ & 0.56 & $21.4 \pm 5.9^{b}$ & 0.54 & $125.8 \pm 22.5^{\mathrm{A}}$ & 1.32 & $27.7 \pm 4.1^{\mathrm{B}}$ & 0.80 \\
\hline sarcosine & $927.1 \pm 194.8^{a}$ & 17.18 & $182.8 \pm 98.5^{b}$ & 5.69 & $457.9 \pm 286.4^{b}$ & 11.57 & $2393.1 \pm 618.4^{\mathrm{A}}$ & 25.15 & $305.0 \pm 38.6^{\mathrm{B}}$ & 8.83 \\
\hline alanine & $296.4 \pm 40.0^{a}$ & 5.49 & $74.7 \pm 31.4^{b}$ & 2.33 & $155.0 \pm 100.4^{b}$ & 3.91 & $605.9 \pm 120.9^{\mathrm{A}}$ & 6.37 & $103.0 \pm 7.3^{B}$ & 2.98 \\
\hline valine & $93.2 \pm 17.9^{a}$ & 1.73 & $27.9 \pm 13.9^{b}$ & 0.87 & $51.0 \pm 21.1^{\mathrm{b}}$ & 1.29 & $147.2 \pm 9.0^{\mathrm{A}}$ & 1.55 & $31.4 \pm 1.7^{\mathrm{B}}$ & 0.91 \\
\hline proline & $1234.0 \pm 54.6^{a}$ & 22.87 & $860.8 \pm 267.9^{a}$ & 26.81 & $979.6 \pm 201.1^{\mathrm{a}}$ & 24.74 & $1532.4 \pm 225.5^{\mathrm{A}}$ & 16.11 & $711.5 \pm 44.9^{C}$ & 20.60 \\
\hline threonine & $55.5 \pm 4.0^{\mathrm{a}}$ & 1.03 & $37.3 \pm 14.4^{\mathrm{a}}$ & 1.16 & $39.0 \pm 13.8^{a}$ & 0.98 & $288.4 \pm 39.8^{\mathrm{A}}$ & 3.03 & $92.6 \pm 10.8^{B}$ & 2.68 \\
\hline isoleucine & $41.9 \pm 9.5^{a}$ & 0.78 & $11.6 \pm 6.2^{b}$ & 0.36 & $22.8 \pm 8.2^{\mathrm{b}}$ & 0.58 & $62.6 \pm 11.3^{\mathrm{A}}$ & 0.66 & $12.2 \pm 1.5^{\mathrm{B}}$ & 0.35 \\
\hline leucine & $32.9 \pm 6.9^{a}$ & 0.61 & $5.5 \pm 2.1^{b}$ & 0.17 & $15.3 \pm 9.6^{b}$ & 0.39 & $25.3 \pm 5.3^{A}$ & 0.27 & $4.8 \pm 1.0^{\mathrm{B}}$ & 0.14 \\
\hline ornithine & $59.4 \pm 4.1^{\mathrm{a}}$ & 1.10 & $53.5 \pm 15.5^{\mathrm{a}}$ & 1.67 & $52.2 \pm 6.6^{a}$ & 1.32 & $208.6 \pm 17.0^{A}$ & 2.19 & $115.8 \pm 8.1^{\mathrm{B}}$ & 3.35 \\
\hline methionine & $2.5 \pm 0.5^{a}$ & 0.05 & $1.2 \pm 0.1^{b}$ & 0.04 & $1.2 \pm 0.1^{b}$ & 0.03 & $12.7 \pm 0.9^{A}$ & 0.13 & $2.1 \pm 0.3^{B}$ & 0.06 \\
\hline histidine & $20.3 \pm 5.4^{\mathrm{a}}$ & 0.38 & $12.4 \pm 1.1^{\mathrm{a}}$ & 0.39 & $21.1 \pm 5.8^{\mathrm{a}}$ & 0.53 & $49.8 \pm 5.1^{\mathrm{A}}$ & 0.52 & $13.3 \pm 2.3^{\mathrm{B}}$ & 0.39 \\
\hline phenylalanine & $23.6 \pm 5.9^{\mathrm{a}}$ & 0.44 & $6.8 \pm 2.0^{\mathrm{b}}$ & 0.21 & $12.9 \pm 7.6^{\mathrm{ab}}$ & 0.33 & $13.4 \pm 4.4^{\mathrm{A}}$ & 0.14 & $3.7 \pm 0.9^{B}$ & 0.11 \\
\hline arginine & $14.6 \pm 1.7^{\mathrm{a}}$ & 0.27 & $6.7 \pm 1.1^{\mathrm{b}}$ & 0.21 & $9.7 \pm 4.5^{\mathrm{ab}}$ & 0.25 & $116.9 \pm 74.2^{\mathrm{A}}$ & 1.23 & $221.7 \pm 27.2^{\mathrm{B}}$ & 6.42 \\
\hline tyrosine & $16.5 \pm 3.1^{\mathrm{a}}$ & 0.31 & $5.9 \pm 1.8^{b}$ & 0.19 & $10.5 \pm 4.3^{\mathrm{ab}}$ & 0.27 & $20.1 \pm 2.5^{\mathrm{A}}$ & 0.21 & $4.0 \pm 1.3^{\mathrm{B}}$ & 0.12 \\
\hline $\begin{array}{l}\text { asparagic } \\
\text { acid }\end{array}$ & $350.5 \pm 6.2^{\mathrm{a}}$ & 6.50 & $339.5 \pm 92.3^{a}$ & 10.57 & $299.4 \pm 16.4^{a}$ & 7.56 & $1224.5 \pm 86.9^{\mathrm{A}}$ & 12.87 & $729.9 \pm 49.4^{B}$ & 21.14 \\
\hline tryptophan & $409.0 \pm 23.2^{\mathrm{a}}$ & 7.58 & $350.4 \pm 114.9^{a}$ & 10.91 & $378.1 \pm 47.6^{\mathrm{a}}$ & 9.55 & $443.7 \pm 192.7^{\mathrm{A}}$ & 4.66 & $229.4 \pm 24.7^{\mathrm{AB}}$ & 6.64 \\
\hline $\begin{array}{l}\text { 4- } \\
\text { aminobutyric } \\
\text { acid }\end{array}$ & $555.5 \pm 57.8^{a}$ & 10.29 & $182.0 \pm 98.9^{b}$ & 5.67 & $334.2 \pm 206.1^{\mathrm{ab}}$ & 8.44 & $792.5 \pm 112.1^{\mathrm{A}}$ & 8.33 & $162.9 \pm 47.3^{\mathrm{B}}$ & 4.72 \\
\hline serine & $73.7 \pm 4.9^{a}$ & 1.36 & $47.1 \pm 8.7^{b}$ & 1.47 & $69.6 \pm 16.8^{a b}$ & 1.76 & $176.9 \pm 40.1^{\mathrm{A}}$ & 1.86 & $50.6 \pm 3.0^{B}$ & 1.47 \\
\hline lysine & $643.5 \pm 50.1^{a}$ & 11.92 & $574.8 \pm 195.1^{\mathrm{a}}$ & 17.90 & $577.8 \pm 119.7^{a}$ & 14.59 & $717.3 \pm 417.3^{\mathrm{A}}$ & 7.54 & $316.5 \pm 35.3^{A}$ & 9.17 \\
\hline glutamate & $508.3 \pm 30.6^{a}$ & 9.42 & $412.6 \pm 103.2^{\mathrm{a}}$ & 12.85 & $450.7 \pm 56.1^{a}$ & 11.38 & $557.6 \pm 213.6^{A}$ & 5.86 & $315.0 \pm 33.4^{\mathrm{AB}}$ & 9.12 \\
\hline sum & $5396.7 \pm 378.0^{a}$ & 100 & $3211.5 \pm 1064.1^{b}$ & 100 & $3959.5 \pm 1108.6^{a b}$ & 100 & $9514.5 \pm 1890.8^{A}$ & 100 & $3453.3 \pm 247.6^{\mathrm{B}}$ & 100 \\
\hline
\end{tabular}


The different lower case and upper case letters indicated significant differences for aboveground and belowground tissues among treatments.

Table 4 Effect of sediment type on flavonoids in the aboveground and belowground tissue seagrass Thalassia hemprichii. 1:0, the in-situ sediment without combining with coarse beach sand was added in the tank; $1: 1$, the combination of half in-situ sediment and half coarse beach sand was added in the tank; $1: 2$, the combination of $1 / 3$ in-situ sediment and $2 / 3$ coarse beach sand was added in the tank.

\begin{tabular}{|c|c|c|c|c|c|c|c|c|c|c|}
\hline \multirow[t]{3}{*}{ Flavonoids } & \multicolumn{6}{|c|}{ Aboveground tissue } & \multicolumn{4}{|l|}{ Belowground tissue } \\
\hline & \multicolumn{2}{|l|}{$1: 0$} & \multicolumn{2}{|l|}{$1: 1$} & \multicolumn{2}{|l|}{$1: 2$} & \multicolumn{2}{|l|}{$1: 0$} & \multicolumn{2}{|l|}{$1: 1$} \\
\hline & content $(\mu \mathrm{g} / \mathrm{g})$ & $\begin{array}{l}\text { ratio } \\
(\%)\end{array}$ & content $(\mu \mathrm{g} / \mathrm{g})$ & $\begin{array}{l}\text { ratio } \\
(\%)\end{array}$ & content $(\mu \mathrm{g} / \mathrm{g})$ & $\begin{array}{l}\text { ratio } \\
(\%)\end{array}$ & content $(\mu \mathrm{g} / \mathrm{g})$ & $\begin{array}{l}\text { ratio } \\
(\%)\end{array}$ & content $(\mu \mathrm{g} / \mathrm{g})$ & $\begin{array}{l}\text { rati } \\
(\%)\end{array}$ \\
\hline catechin & $0.0223 \pm 0.0065^{a}$ & 0.55 & $0.0090 \pm 0.0041^{b}$ & 0.33 & $0.0115 \pm 0.0033^{b}$ & 0.43 & $14.4433 \pm 5.4480^{\mathrm{A}}$ & 67.56 & $1.1228 \pm 0.0646^{\mathrm{B}}$ & 31.: \\
\hline epicatechin & nd & & nd & & nd & & $1.2517 \pm 0.1782^{A}$ & 5.85 & $0.0437 \pm 0.0016^{\mathrm{B}}$ & 1.2: \\
\hline taxifolin & nd & & 0.0068 & 0.25 & nd & & $0.0219 \pm 0.0101^{A}$ & 0.10 & $0.0146 \pm 0.0096^{A}$ & 0.4 \\
\hline galuteolin & $1.9969 \pm 0.6946^{\mathrm{a}}$ & 49.97 & $1.5255 \pm 0.9832^{\mathrm{a}}$ & 55.46 & $1.6700 \pm 1.0298^{\mathrm{a}}$ & 62.55 & $0.0033 \pm 0.0013^{\mathrm{A}}$ & 0.02 & $0.0069 \pm 0.0037^{A}$ & $0.1^{\prime}$ \\
\hline rutin & $0.0049 \pm 0.0041^{\mathrm{a}}$ & 0.12 & $0.0024 \pm 0.0007^{a}$ & 0.09 & $0.0026 \pm 0.0009^{a}$ & 0.1 & $0.0116 \pm 0.0057^{A}$ & 0.05 & $0.0025 \pm 0.0001^{B}$ & $0.0^{\circ}$ \\
\hline isoquercitrin & $0.4959 \pm 0.2699^{a}$ & 12.41 & $0.1903 \pm 0.1332^{\mathrm{a}}$ & 6.94 & $0.2901 \pm 0.1066^{\mathrm{a}}$ & 10.87 & $5.2404 \pm 1.1379^{A}$ & 24.51 & $1.4558 \pm 0.4994^{\mathrm{B}}$ & 40. \\
\hline astragalin & nd & & nd & & nd & & $0.0135 \pm 0.0016^{A}$ & 0.06 & $0.0102 \pm 0.0011^{B}$ & $0.2 i$ \\
\hline diosmin & $0.0027 \pm 0.0006^{a}$ & 0.07 & $0.0040 \pm 0.0008^{a}$ & 0.15 & $0.0034 \pm 0.0007^{a}$ & 0.13 & $\mathrm{Nd}$ & & nd & \\
\hline quercetin & $0.0439 \pm 0.0166^{a}$ & 1.10 & $0.0076 \pm 0.0061^{b}$ & 0.28 & $0.0165 \pm 0.0047^{b}$ & 0.62 & $0.3283 \pm 0.0829^{A}$ & 1.54 & $0.0544 \pm 0.0068^{B}$ & $1.5^{\circ}$ \\
\hline naringenin & $0.0175 \pm 0.0095^{a}$ & 0.44 & $0.0087 \pm 0.0021^{a}$ & 0.32 & $0.0067 \pm 0.0018^{a}$ & 0.25 & $0.0073 \pm 0.0015^{A}$ & 0.03 & $0.0187 \pm 0.0073^{B}$ & 0.5 \\
\hline luteolin & $1.3468 \pm 0.2366^{a}$ & 33.70 & $0.9275 \pm 0.4247^{a b}$ & 33.83 & $0.6227 \pm 0.2648^{b}$ & 23.33 & $0.0581 \pm 0.0246^{\mathrm{A}}$ & 0.27 & $0.8522 \pm 0.6017^{B}$ & 23.1 \\
\hline apigenin & $0.0628 \pm 0.0223^{a}$ & 1.57 & $0.0631 \pm 0.0118^{a}$ & 2.30 & $0.0443 \pm 0.0137^{a}$ & 1.66 & $0.0005 \pm 0.000^{\mathrm{A}}$ & 0.01 & $0.0153 \pm 0.0131^{C}$ & $0.4:$ \\
\hline chrysin & $0.0013 \pm 0.0003^{a}$ & 0.03 & $0.0006 \pm 0.0001^{b}$ & 0.02 & $0.0008 \pm 0.0001^{b}$ & 0.03 & $\mathrm{Nd}$ & & $0.0018 \pm 0.0007$ & $0.0 !$ \\
\hline kaempferide & $0.0015 \pm 0.0007^{a}$ & 0.04 & $0.0009 \pm 0.0001^{\mathrm{a}}$ & 0.03 & $0.0007 \pm 0.0002^{\mathrm{a}}$ & 0.03 & $\mathrm{Nd}$ & & nd & \\
\hline sum & $3.9956 \pm 1.1751^{\mathrm{a}}$ & 100 & $2.7421 \pm 1.5258^{a}$ & 100 & $2.6691 \pm 1.4033^{a}$ & 100 & $21.3797 \pm 6.4628^{A}$ & 100 & $3.5973 \pm 1.1740^{\mathrm{B}}$ & $10 C$ \\
\hline
\end{tabular}

nd: not detectable (i.e. below the limit of detection); the different lower case and upper case letters indicated significant differences for aboveground and belowground tissues among treatments.

Table 5 Statistical analysis for the effects of sediment type on dynamic properties of Thalassia hemprichii. There were two stages for photosynthetic parameters. $P<0.05$ (significant); $P<0.01$ (highly significant) 


\begin{tabular}{|c|c|c|c|c|c|c|c|}
\hline Variable & df & $\mathrm{F}$ & $P$ & Variable & df & $\mathrm{F}$ & $P$ \\
\hline Day 6 & & & & Day 21 & & & \\
\hline $\mathrm{F}_{0}^{\prime}$ & 2 & 1.309 & 0.338 & $\mathrm{~F}_{0}^{\prime}$ & 2 & 0.633 & 0.563 \\
\hline $\mathrm{F}_{\mathrm{m}}{ }^{\prime}$ & 2 & 1.081 & 0.397 & $\mathrm{~F}_{\mathrm{m}}{ }^{\prime}$ & 2 & 0.292 & 0.757 \\
\hline$F_{v}{ }^{\prime} / F_{m}{ }^{\prime}$ & 2 & 1.412 & 0.314 & $\mathrm{~F}_{\mathrm{v}}{ }^{\prime} / \mathrm{F}_{\mathrm{m}}{ }^{\prime}$ & 2 & 1.727 & 0.256 \\
\hline ETR $_{\max }$ & 2 & 2.141 & 0.199 & $\mathrm{ETR}_{\max }$ & 2 & 4.817 & 0.057 \\
\hline $\mathrm{E}_{\mathrm{k}}$ & 2 & 0.565 & 0.596 & $E_{k}$ & 2 & 3.914 & 0.082 \\
\hline a & 2 & 0.332 & 0.730 & $a$ & 2 & 1.183 & 0.242 \\
\hline$\beta$ & 2 & 0.037 & 0.964 & $\beta$ & 2 & 13.663 & $<0.01$ \\
\hline leaf nitrogen & 2 & 62.547 & $<0.01$ & $\delta^{34} s$ & 2 & 629.078 & $<0.01$ \\
\hline ratio of amino acid to leaf nitrogen & 2 & 6.708 & $<0.05$ & Organic matter & 2 & 13.158 & $<0.01$ \\
\hline Eh & 2 & 21.653 & $<0.01$ & S & 2 & 59.828 & $<0.01$ \\
\hline aboveground tissue & & & & belowground tissue & & & \\
\hline glycine & 2 & 12.702 & $<0.01$ & glycine & 2 & 92.525 & $<0.01$ \\
\hline sarcosine & 2 & 9.832 & $<0.05$ & sarcosine & 2 & 23.737 & $<0.01$ \\
\hline alanine & 2 & 8.964 & $<0.05$ & alanine & 2 & 41.459 & $<0.01$ \\
\hline valine & 2 & 10.335 & $<0.05$ & valine & 2 & 204.800 & $<0.01$ \\
\hline proline & 2 & 2.841 & 0.136 & proline & 2 & 41.100 & $<0.01$ \\
\hline threonine & 2 & 2.181 & 0.194 & threonine & 2 & 134.373 & $<0.01$ \\
\hline isoleucine & 2 & 10.712 & $<0.05$ & isoleucine & 2 & 73.448 & $<0.01$ \\
\hline leucine & 2 & 12.082 & $<0.01$ & leucine & 2 & 66.719 & $<0.01$ \\
\hline ornithine & 2 & 0.435 & 0.666 & ornithine & 2 & 42.395 & $<0.01$ \\
\hline methionie & 2 & 21.875 & $<0.01$ & methionie & 2 & 306.695 & $<0.01$ \\
\hline histidine & 2 & 3.281 & 0.109 & histidine & 2 & 122.650 & $<0.01$ \\
\hline phenylalanine & 2 & 6.683 & $<0.05$ & phenylalanine & 2 & 19.644 & $<0.01$ \\
\hline arginine & 2 & 5.777 & $<0.05$ & arginine & 2 & 14.548 & $<0.01$ \\
\hline tyrosine & 2 & 8.073 & $<0.05$ & tyrosine & 2 & 94.401 & $<0.01$ \\
\hline asparagic acid & 2 & 0.737 & 0.517 & asparagic acid & 2 & 39.413 & $<0.01$ \\
\hline tryptophan & 2 & 0.484 & 0.639 & tryptophan & 2 & 3.826 & 0.085 \\
\hline 4-aminobutyric acid & 2 & 5.708 & $<0.05$ & 4-aminobutyric acid & 2 & 57.394 & $<0.01$ \\
\hline serine & 2 & 4.827 & 0.056 & serine & 2 & 117.694 & $<0.01$ \\
\hline lysine & 2 & 0.247 & 0.789 & lysine & 2 & 2.830 & 0.136 \\
\hline glutamate & 2 & 1.419 & 0.313 & glutamate & 2 & 3.955 & $<0.080$ \\
\hline total amino acids & 2 & 4.433 & 0.066 & total amino acids & 2 & 76.191 & $<0.01$ \\
\hline catechin & 2 & 6.456 & $<0.05$ & catechin & 2 & 19.131 & $<0.01$ \\
\hline epicatechin & 2 & - & - & epicatechin & 2 & 143.001 & $<0.01$ \\
\hline taxifolin & 2 & - & - & taxifolin & 2 & 0.590 & 0.584 \\
\hline galuteolin & 2 & 0.209 & 0.817 & galuteolin & 2 & 2.146 & 0.198 \\
\hline rutin & 2 & 0.942 & 0.441 & rutin & 2 & 3.498 & 0.098 \\
\hline isoquercitrin & 2 & 2.143 & 0.198 & isoquercitrin & 2 & 12.003 & $<0.01$ \\
\hline astragalin & 2 & - & - & astragalin & 2 & 4.119 & 0.075 \\
\hline diosmin & 2 & 2.616 & 0.152 & diosmin & 2 & - & - \\
\hline quercetin & 2 & 9.660 & $<0.05$ & quercetin & 2 & 35.336 & $<0.01$ \\
\hline
\end{tabular}




\begin{tabular}{|llllllll|} 
naringenin & 2 & 3.003 & 0.125 & naringenin & 2 & 5.609 & $<0.05$ \\
luteolin & 2 & 3.882 & 0.083 & luteolin & 2 & 4.859 & 0.056 \\
\hline apigenin & 2 & 1.279 & 0.345 & apigenin & 2 & 23.055 & $<0.01$ \\
\hline chrysin & 2 & 8.173 & $<0.05$ & chrysin & 2 & - & - \\
kaempferide & 2 & 3.753 & 0.088 & kaempferide & 2 & - & - \\
\hline total flavonoids & 2 & 0.883 & 0.461 & total flavonoids & 2 & 26.375 & $<0.01$ \\
\hline
\end{tabular}

Table 6 Correlation coefficients $(r)$ and significance values $(p)$ between the total flavonoids and amino acids concentration and sediment sand composition.

\begin{tabular}{|lll|}
\hline Parameters & $r$ & $P$ \\
\hline Amino acids in aboveground tissue & -0.682 & $<0.05$ \\
\hline Amino acids in belowground tissue & -0.928 & $<0.01$ \\
\hline Flavonoids in aboveground tissue & -0.475 & 0.197 \\
\hline Flavonoids in belowground tissue & -0.933 & $<0.01$ \\
\hline
\end{tabular}

\section{Discussion}

Decreased sediment particle size induced by increased inputs of macroalgae detritus and fish food debris undoubtedly led to anoxia condition. Seagrass growth and survival maybe constrained by anoxia sediment conditions. Anoxia has been regarded as one of the most harmful factors for plants as a result of the accumulation of toxic end products (Pérez et al. 2007). Meanwhile, sulfide toxicity is considered one of the contributing factors for seagrass beds decline as well (Grignon-Dubois and Rezzonico 2018). Under such circumstance, seagrass photosynthesis would be directly affected and it could regulate response through changes in primary and secondary metabolics. To the best of our knowledge, this was the first report on the response of seagrass secondary metabolic to environmental stress using targeted metabolomics.

\section{Seagrass photosynthesis was indirectly enhanced by adding coarse beach sand}

Seagrass-sediment interactions are dynamics (de Boer 2007). The present results showed that effective quantum yield has no significant difference at both stages among the treatments, implying that this parameter was not a good indicator of stress. Meanwhile, there was little change in the parameters of rapid light curve at day 6 among the treatments, indicating this effect was not obvious at the initial stage. However, a noticeably enhancement in RETR $\mathrm{R}_{\text {max }}$ and $\mathrm{E}_{\mathrm{k}}$ were observed at day 21 (at the end of the experiment) under coarse beach sand addition treatment, suggesting the ability to transfer more electrons and a larger energy investment for $\mathrm{CO}_{2}$ fixation in T. hemprichii. Similarly, higher sand composition induced higher Eh, indicating that coarse beach sand addition increased the porosity of sediment therefore benefited the oxygen permeation. This more favorable condition might favor seagrass growth by enhancing photosynthesis. Vise verse, higher photosynthesis also induced positive effect on sediment redox potential (Marbà et al. 2010). High photosynthesis resulted in greater pools of $\mathrm{O}_{2}$ in below-ground tissues, enhancing radial $\mathrm{O}_{2}$ loss and the oxic shield (Koch and Erskine 2001; Oakes and Connolly 2004). Furthermore, the $\mathrm{O}_{2}$ consumption by seagrass roots increased with increasing shoot-to-root mass ratio, which was dominated by root mass and disrupted by sulfide (Peyer et al. 2020). However, muddy sediments might be more favourable for Zostera marina than sandy sediments, though it can be grown in either sediment (van Katwijk and Wijgergangs 2004). Sediment with high silt and clay content could promote successful transplantation of $Z$. marina (Zhang et al. 2015). The sediment's effect might show specific difference. Some species such as $Z$. marina and Cymodocea nodosa showed greater tolerance to reducing conditions in sediments than T. hemprichii (Pérez et al. 2007).

\section{Belowground amino acids and flavonoids were stimulated to counteract anoxic stress in sediment with smaller particle sizes}

Amino acids are of great importance for protein biosynthesis, other metabolic pathways and in the signal transduction processes (D'Mello 2015). Proline and sarcosine were the main amino acids in the both aboveground and belowground tissues of $T$. hemprichii. For $P$. oceanica, asparagic acid, asparagine and glutamate were the chief amino acids in leaves, while asparagic acid, serine and alanine were the dominant components in the roots. Furthermore, proline were the main amino acids in the both aboveground and belowground tissue of Cymodocea nodosa (Pirc and Wollenweber 1988). The amino acids may change substantially in response to environmental factors. The present study indicated that the total amino acid contents in the aboveground and belowground tissues were both higher in the smaller sediment particle sizes. Especially, the belowground amino acid concentration in the smaller sediment particle sizes exhibited more than two times of that in the larger sediment particle sizes. There were two reasons to explain this phenomenon. One could be explained by that increased ammonium assimilation induced by higher nitrogen content in the sediment with smaller particle sizes (de Kock et al. 2020). The other could be associated with the adverse effect of lower oxygen condition. Higher alanine (an end product of anaerobic fermentation in higher plants) and proline contents in the both aboveground and belowground tissues of $T$. hemprichii were observed in the smaller sediment particle size with lower Eh. Similarly, Z. marina also accumulated the amino acids alanine under anoxia (Bailey-Serres et al. 2012; Pregnall 2004). The rhizomes of Posidonia oceanica had increased alanine concentrations as well to adapt anoxia exposure (Pérez et al. 2007). The enhancement of alanine is a known phenomenon due to pyruvate accumulation in plants subjected to anoxia, which would mitigate cell acidification (D'Mello 2015; Hasler-Sheetal et al. 2015), and provides support for carbon metabolism and energy homesostasis by linking glycolysis with the tricarboxylic acid cycle (Yordanova and Popova 2007). The increase in alanine 
takes place at the expense of glutamate and aspartate, and concomitantly with the accumulation of GABA (Good and Muench 1993). Furthermore, leucine and valine, the two branched-chain amino acids, were also enhanced, which could be de novo synthesized from pyruvate (D'Mello 2015). Proline in most of the higher plants under environmental constraints including salinity, drought and anaerobiosis often responses with an increase (D'Mello 2015). The accumulation of proline was due to an increase in proline synthesis from glutamate as well as a decrease in proline oxidation (Huang and Cavalieri 1979; Szabados and Savoure 2010). The increased proline content also like factor of free radicals detoxification in flooded corn plants (Yordanova and Popova 2007). Moreover, excess sulfate is also reduced to sulfide and incorporated into methionine, the sulfur-containing amino acid (Nikiforova et al. 2006). Significantly higher methionine in the belowground tissue was observed in the smaller sediment particle sizes, indicating the biosynthesis of methionine might function as the detoxification agent for excess sulfate or sulfide. Similarly, Z. marina also detoxified gaseous sediment-derived sulfide through incorporation and that most of the detoxification occurred in belowground tissues, where sulfide intrusion was greatest (Hasler-Sheetal and Holmer 2015).

Among phenolic compounds, flavonoids have all the potentialities to constitute reliable biomarkers of environmental quality (Cannac et al. 2006). The present study indicated galuteolin and luteolin were the prime flavones in the leaf of $T$. hemprichii, while catechin and isoquercitrin were the main composition in the belowground tissue. For P. oceanica, myricetin and Isorhamnetin were the chief composition of leaf flavonols (Cannac et al. 2006). The flavonoid of Halophila stipulacea was dominated by apigenin-7-0- $\beta$-glucopyranoside co-occurring with other minor flavone glucosides containing two malonyl derivatives (Bitam et al. 2010). Seagrasses with larger leaves and/or more pairs of cross veins in the leaves contained sulfated flavonoids, while those with smaller leaves and/or fewer cross veins lack these compounds (McMillan 1986). The difference might be associated with the measurement method or specific difference. Although there were considerable differences among the different methods regarding flavonoid content in seagrass, none modified the flavonoid profile (Cannac et al. 2007). Low-oxygen stress changed the expression of metabolic genes such as flavonoid biosynthesis, and induced the process of flavonoid biosynthesis that involve methylation as a modification of compounds to accomplish activation or intracellular translocation (Klok et al. 2002). The present study showed that lower flavonoids concentration in the belowground tissue was observed in the sediment with larger particle size. Similarly, a decrease in the total phenolic concentrations in Z. marina was also found when grown in high $\mathrm{pCO}_{2}$ waters (Arnold et al. 2014). This might attributed to a reallocation of carbon to other pathways (Groner et al. 2018). Phenolic compounds are regarded as storage compounds for carbohydrates, which are only produced when the plants cannot convert the carbohydrates into growth (Cannac et al. 2006; Waterman et al. 1984). Ecological plant strategy theory implies that plants investing into biochemical means of stress protection are likely to invest less carbon into constitutive productivity (Grime 2001). A trade-off mechanism between growth and secondary production for protection might occur in the present study, which needed further study. Interestingly, the $\delta^{34} S$ in the belowground tissue of $T$. hemprichii was more positive in the sediment with smaller particle size, which was similar to the change of belowground flavonoid. Sulfation of flavonoids might facilitate the consumption of the sulfide intruded, functioning as detoxification agent (Grignon-Dubois and Rezzonico 2018). Z. marine and T. testudinum, rich in flavonoid sulfates, could tolerate higher sulfide intrusion than $P$. oceanica, almost total absence of flavonoid (Grignon-Dubois and Rezzonico 2015; 2018; Harborne 1975; McMillan et al. 1980; Rowley et al. 2002). 50\% of the radiolabeled sulfate fed to Z. marina was recovered in the phenolic flavonoid fraction (Nissen and Benson 1964). Furthermore, less leaf flavonoid was beneficial for the carbon transfer through food chain since flavonoid is a chemical defense against herbivores (Zidorn 2016). Flavonoid sulfates might play a key role in seagrasses's allelochemical relations (GrignonDubois and Rezzonico 2012; McMillan et al. 1980). Especially, catechin was extremely higher in the belowground tissue of T. hemprichii in the sediment with smaller particle size. Catechin might play a crucial role in the response to anoxic condition. Exogenous catechin can markedly reduce the waterlogging injury in roots by enhancing free radical scavenging system sufficiently to lower hydrogen peroxide and superoxide concentrations (Yiu et al. 2011).

In the present study, a strong positive correlation between flavonoids and amino acids indicated that the amino acids were a good indicator of the flavonoid accumulation. The available aromatic amino acids are intended for the flavonoid pathway and provided by the primary metabolism (Trantas et al. 2015), which was confirmed by that aromatic amino acid includes phenylalanine, tryptophan and tyrosine were higher in the in-situ sediment. Meanwhile, leucine and valine serve as precursors of plant secondary metabolites. Further research will be needed to perform a cross phytochemical/phylogenetic analysis of seagrasses to correlate the phenolic fingerprint and the amino acid sequences of genes encoding the flavonoid pathway (Grignon-Dubois and Rezzonico 2012).

\section{Ecological Significance}

Sediment type is undoubtedly a key factor influencing seagrass distribution, growth, abundance and the success of seagrass transplantation (de Boer 2007; Livingston et al. 1998). In recent years, the modification of sediment structure and composition by removing polluted sediment and adding exogenous matrix has often been applied in better protecting submerged plants and the ecological restoration project of rivers and lakes (Li et al. 2016; Lin Liu et al. 2016; Smart 1986). However, modification of sediment type was less considered and applied in the ecological restoration of wetland, especially in the seagrass beds suffering from eutrophication. Seagrasses in the sediment with smaller particle sizes exhibited lower ETR $\mathrm{max}_{\max }$ and $\mathrm{E}_{\mathrm{k}}$, indicating a decrease in light tolerance (Fig. 6). Organic matter input from shrimp pond culture along the coastline in Xincun bay resulted in smaller sediment particle size. This induced that $T$. hemprichii in the high intertidal suffered more from high light stress during air exposure, causing faster decline in the high intertidal than in the lower intertidal. The present study proved that adding coarse beach sand would reduce sediment total nitrogen, organic matter and sulfur content, and enhance oxygen permeability in the hypoxic/anoxic sediment, leading to less synthesis of amino acid and flavonoid. This would benefit seagrass photosynthesis and allocate more carbon to growth. Furthermore, stimulated photosynthesis also led to less toxic substance accumulation by increasing oxygenated condition in the rhizosphere (Marbà et al. 2010), and seagrasses do not have to transfer the photosynthetic products e.g. carbohydrates and secondary metabolites to overcome the toxic effects from sulfide. This would benefit and accelerate seagrass growth. The enhancement of ETR $R_{\text {max }}$ and $E_{k}$ may partially offset negative effects of reduced light irradiance on $\mathrm{C}$ balance and improve the high light tolerance. Especially, seagrass beds in the world have faced with increased eutrophication caused by large input of nutrients from anthropogenic activity (de Kock et al. 2020; Jiang et al. 2018; Marbà et al. 2014). Field observation concerning seagrass response to sediment type are needed at an ecosystem level if we are to determine operable habitat requirements of seagrasses (Livingston et al. 1998). It is also very important to change the sediment type to improve the growth condition for seagrass and to enhance the successful rate in planting and transplanting seagrass shoots in the eutrophicated ecosystem. Furthermore, T. hemprichii is gradually being replaced by Enhalus acoroides

Page $9 / 14$ 
due to decreasing sediment particle size. Meanwhile, sediment type also affected interspecific competition between the salt marsh plants (Li et al. 2014). Thus, further study on the effect of changing sediment on interspecific competition and community succession for seagrasses are also needed and to be enhanced.

Together, our results indicate that coarse beach sand addition could indirectly enhance the photosynthesis of Thalassia hemprichii by improving sediment condition with lower total nitrogen, organic matter and sulfide intrusion. Meanwhile, considerably greater belowground amino acid and flavonoid were observed to counteract anoxic stress in the sediment with smaller particle size, leading to more positive belowground $\delta^{34} \mathrm{~S}$. Consequently, there is possible that sediment could be modified in the eutrophicated bay to improve the growth condition for tropical dominant seagrass $T$. hemprichii. However, more detailed analysis and field experiment are required to determine this. Furthermore, further studies are needed to examine the metabolic pathway of key primary and secondary metabolics of seagrass, and the trade-off mechanism between growth and defense, under sediment modification.

\section{Abbreviations}

RETR $_{\text {max }}$, relative maximum electron transport rate; $E_{k}$, minimum saturating irradiance; $a$, the initial slope of the light limited relationship; $\beta$, down-regulation; 1:0, the in-situ sediment without combining with coarse beach sand was added in the tank; 1:1, the combination of half in-situ sediment and half coarse beach sand was added in the tank; $1: 2$, the combination of $1 / 3$ in-situ sediment and $2 / 3$ coarse beach sand was added in the tank.

\section{Declarations}

Acknowledgements: This research was supported by the National Natural Science Foundation of China (nos. 41976144, 41730529), Key Special Project for Introduced Talents Team of Southern Marine Science and Engineering Guangdong Laboratory (Guangzhou)(GML2019ZD0405), the Natural Science Fund of Guangdong (2019A1515010552), the National Key Research and Development Program of China (2017YFC0506104), the National Specialized Project of Science and Technology (2015FY110600), and the Innovation Academy of South China Sea Ecology and Environmental Engineering, Chinese Academy of Sciences (ISEE2018PY01, ISEE2018ZD02).

\section{References}

1. Arnold T, Freundlich G, Weilnau T, Verdi A, Tibbetts IR (2014) Impacts of groundwater discharge at myora springs (North Stradbroke Island, Australia) on the phenolic metabolism of eelgrass, Zostera muelleri, and grazing by the juvenile rabbitfish, Siganus fuscescens. PloS one 9: e104738

2. Bailey-Serres J, Fukao T, Gibbs DJ, Holdsworth MJ, Lee SC, Licausi F, Perata P, Voesenek LA, van Dongen JT (2012) Making sense of low oxygen sensing. Trends Plant Sci 17: 129-138

3. Beer S, Björk M (2000) Measuring rates of photosynthesis of two tropical seagrasses by pulse amplitude modulated (PAM) fluorometry. Aquat Bot 66: 6976

4. Beer S, Björk M, Gademann R, Ralph P (2001) Measurements of photosynthetic rates in seagrasses. In: F Short, R Coles (eds) Global Seagrass Research Methods. Elsevier, Amsterdam

5. Bishop MJ, Kelaher BP (2013) Replacement of native seagrass with invasive algal detritus: impacts to estuarine sediment communities. Biol Invasions 15: 45-59. doi: 10.1007/s10530-012-0267-0

6. Bitam F, Ciavatta ML, Carbone M, Manzo E, Mollo E, Gavagnin M (2010) Chemical analysis of flavonoid constituents of the seagrass Halophila stipulacea: First finding of malonylated derivatives in marine phanerogams. Biochem Syst Ecol 38: 686-690. doi:

https://doi.org/10.1016/j.bse.2010.04.007

7. Burkholder JM, Tomasko DA, Touchette BW (2007) Seagrasses and eutrophication. Journal of Experimental Marine Biology and Ecology $350: 46-72$

8. Cannac M, Ferrat L, Barboni T, Pergent G, Pasqualini V (2007) The influence of tissue handling on the flavonoid content of the aquatic plant Posidonia oceanica. J Chem Ecol 33: 1083-1088

9. Cannac M, Ferrat L, Pergent-Martini C, Pergent G, Pasqualini V (2006) Effects of fish farming on flavonoids in Posidonia oceanica. Science of The Total Environment 370: 91-98. doi: http://dx.doi.org/10.1016/j.scitotenv.2006.07.016

10. Chiu S-H, Huang Y-H, Lin H-J (2013) Carbon budget of leaves of the tropical intertidal seagrass Thalassia hemprichii. Estuar Coast Shelf Sci 125: 27-35. doi: https://doi.org/10.1016/j.ecss.2013.03.026

11. D'Mello JF (2015) Amino acids in higher plants. CABI, Osfordshire, UK

12. de Boer WF (2007) Seagrass-sediment interactions, positive feedbacks and critical thresholds for occurrence: a review. Hydrobiologia 591: 5-24. doi: $10.1007 /$ s10750-007-0780-9

13. de Kock W, Hasler-Sheetal H, Holmer M, Tsapakis M, Apostolaki ET (2020) Metabolomics and traditional indicators unveil stress of a seagrass (Cymodocea nodosa) meadow at intermediate distance from a fish farm. Ecol Indicators 109: 105765. doi: https://doi.org/10.1016/j.ecolind.2019.105765

14. Folk RL, Andrews P, Lewis DW (1970) Detrital sedimentary rock classification and nomenclature for use in New Zealand. N Z J Geol Geophys 13: $937-968$ 15. Good AG, Muench DG (1993) Long-term anaerobic metabolism in root tissue (metabolic products of pyruvate metabolism). Plant Physiol 101: 1163-1168

16. Grignon-Dubois M, Rezzonico B (2012) First phytochemical evidence of chemotypes for the seagrass Zostera noltii. Plants 1: 27-38

17. Grignon-Dubois M, Rezzonico B (2015) Phenolic fingerprint of the seagrass Posidonia oceanica from four locations in the Mediterranean Sea: First evidence for the large predominance of chicoric acid. Bot Mar 58: 379-391

Page $10 / 14$ 
18. Grignon-Dubois M, Rezzonico B (2018) Phenolic chemistry of the seagrass Zostera noltei Part 1: First evidence of three infraspecific flavonoid chemotypes in three distinctive geographical regions. Phytochemistry 146: 91-101

19. Grime J (2001) Plant strategies, vegetation processes, and ecosystem properties. Chichester: John Wiley and Sons. 417 p.

20. Groner ML, Burge CA, Cox R, Rivlin ND, Turner M, Van Alstyne KL, Wyllie-Echeverria S, Bucci J, Staudigel P, Friedman CS (2018) Oysters and eelgrass: potential partners in a high $\mathrm{pCO}_{2}$ Ecology 99: 1802-1814

21. Hammer KJ, Borum J, Hasler-Sheetal H, Shields EC, Sand-Jensen K, Moore KA (2018) High temperatures cause reduced growth, plant death and metabolic changes in eelgrass Zostera marina. Mar Ecol Prog Ser 604: 121-132

22. Harborne JB (1975) Flavonoid sulphates: a new class of sulphur compounds in higher plants. Phytochemistry 14: 1147-1155

23. Hasler-Sheetal H, Fragner L, Holmer M, Weckwerth W (2015) Diurnal effects of anoxia on the metabolome of the seagrass Zostera marina. Metabolomics 11: 1208-1218

24. Hasler-Sheetal H, Holmer M (2015) Sulfide intrusion and detoxification in the seagrass Zostera marina. PloS one 10: e0129136

25. Heiri O, Lotter AF, Lemcke G (2001) Loss on ignition as a method for estimating organic and carbonate content in sediments: reproducibility and comparability of results. J Paleolimnol 25: 101-110. doi: 10.1023/A:1008119611481

26. Hemminga M, Duarte CM (2000) Seagrass Ecology. Cambridge University Press, Cambridge

27. Holmer M, Hasler-Sheetal H (2014) Sulfide intrusion in seagrasses assessed by stable sulfur isotopes-a synthesis of current results. Front Mar Sci 1. doi: $10.3389 /$ fmars.2014.00064

28. Huang AH, Cavalieri AJ (1979) Proline oxidase and water stress-induced proline accumulation in spinach leaves. Plant Physiol 63: 531-535

29. Huang X, Jiang Z, Liu S, Yu S, Wu Y, Zhang J (2019) Study on Ecology of Tropical Seagrass in China. Science China Press, Beijing

30. Jiang Z, Liu S, Zhang J, Wu Y, Zhao C, Lian Z, Huang X (2018) Eutrophication indirectly reduced carbon sequestration in a tropical seagrass bed. Plant Soil 426: 135-152

31. Jiang Z, Liu S, Zhang J, Zhao C, Wu Y, Yu S, Xia Z, Chi H, Huang X, Kumar M (2017) Newly discovered seagrass beds and their potential for blue carbon in the coastal seas of Hainan Island, South China Sea. Mar Pollut Bull 125: 513-521

32. Klok EJ, Wilson IW, Wilson D, Chapman SC, Ewing RM, Somerville SC, Peacock WJ, Dolferus R, Dennis ES (2002) Expression profile analysis of the lowoxygen response in Arabidopsis root cultures. The Plant Cell 14: 2481-2494

33. Koch MS, Erskine JM (2001) Sulfide as a phytotoxin to the tropical seagrass Thalassia testudinum: interactions with light, salinity and temperature. J Exp Mar Biol Ecol 266: 81-95. doi: https://doi.org/10.1016/S0022-0981(01)00339-2

34. Kumar M, Kuzhiumparambil U, Pernice M, Jiang Z, Ralph PJ (2016) Metabolomics: an emerging frontier of systems biology in marine macrophytes. Algal Res 16: 76-92. doi: https://doi.org/10.1016/j.algal.2016.02.033

35. Kumar M, Ralph P (2017) Systems Biology of Marine Ecosystems. Springer, Switzerland

36. Larkum AW, Orth RRJ, Duarte CM (2006) Seagrasses: Biology, Ecology, and Conservation. Springer, Berlin, Germany

37. Lee HT, Golicz AA, Bayer PE, Jiao Y, Tang H, Paterson AH, Sablok G, Krishnaraj RR, Chan CKK, Batley J (2016) The genome of a southern hemisphere seagrass species (Zostera muelleri). Plant Physiol 172: 272-283

38. Li F, Qin Y, Zhu L, Xie Y, Liang S, Hu C, Chen X, Deng Z (2016) Effects of fragment size and sediment heterogeneity on the colonization and growth of Myriophyllum spicatum. Ecol Eng 95: 457-462. doi: https://doi.org/10.1016/j.ecoleng.2016.06.097

39. Li HL, Wang YY, An SQ, Zhi YB, Lei GC, Zhang MX (2014) Sediment type affects competition between a native and an exotic species in coastal China. Sci Rep 4: 6748

40. Li Q, Huang W, Zhou Y (2010) A preliminary study of eutrophication and occurrence of red tides in Xincun Harbour. T Oceanol Limnol 4: 9-15

41. Lin Liu, Xiang-Qi Bu, Jun-Yan Wan, Bi-Cheng Dong, Fang-Li Luo, Hong-Li Li, Fei-Hai Yu (2016) Impacts of sediment type on the performance and composition of submerged macrophyte communities. Aquat Ecol 51: 1-10

42. Liu S, Jiang Z, Wu Y, Deng Y, Chen Q, Zhao C, Cui L, Huang X (2019) Macroalgae bloom decay decreases the sediment organic carbon sequestration potential in tropical seagrass meadows of the South China Sea. Marine pollution bulletin 138: 598-603

43. Liu S, Jiang Z, Zhang J, Wu Y, Lian Z, Huang X (2016) Effect of nutrient enrichment on the source and composition of sediment organic carbon in tropical seagrass beds in the South China Sea. Mar Pollut Bull 110: 274-280

44. Livingston RJ, McGlynn SE, Niu X (1998) Factors controlling seagrass growth in a gulf coastal system: Water and sediment quality and light. Aquat Bot 60: 135-159. doi: https://doi.org/10.1016/S0304-3770(97)00079-X

45. Marbà N, Díaz-Almela E, Duarte CM (2014) Mediterranean seagrass (Posidonia oceanica) loss between 1842 and 2009. Biol Conserv 176: 183-190. doi: doi: 10.1016/j.biocon.2014.05.024

46. Marbà N, Duarte CM, Terrados J, Halun Z, Gacia E, Fortes MD (2010) Effects of seagrass rhizospheres on sediment redox conditions in SE Asian coastal ecosystems. Estuar Coast 33: 107-117. doi: 10.1007/s12237-009-9250-0

47. McMillan C (1986) Sulfated flavonoids and leaf morphology in the Halophila ovalis-H. minor complex (Hydrocharitaceae) of the Indo-Pacific Ocean. Aquat Bot 25: 63-72. doi: https://doi.org/10.1016/0304-3770(86)90040-9

48. McMillan C, Zapata O, Escobar L (1980) Sulphated phenolic compounds in seagrasses. Aquat Bot 8: 267-278

49. Nikiforova V, Bielecka M, Gakiere B, Krueger S, Rinder J, Kempa S, Morcuende R, Scheible W-R, Hesse H, Hoefgen R (2006) Effect of sulfur availability on the integrity of amino acid biosynthesis in plants. Amino acids 30: 173-183

50. Nissen P, Benson AA (1964) Absence of selenate esters and "selenolipid" in plants. Biochimica et Biophysica Acta 82: 400-402

Page 11/14 
51. Oakes JM, Connolly RM (2004) Causes of sulfur isotope variability in the seagrass, Zostera capricorni. Journal of Experimental Marine Biology and Ecology 302: 153-164. doi: https://doi.org/10.1016/j.jembe.2003.10.011

52. Olsen JL, Rouzé P, Verhelst B, Lin Y-C, Bayer T, Collen J, Dattolo E, De Paoli E, Dittami S, Maumus F, Michel G, Kersting A, Lauritano C, Lohaus R, Töpel M, Tonon T, Vanneste K, Amirebrahimi M, Brakel J, Boström C, Chovatia M, Grimwood J, Jenkins JW, Jueterbock A, Mraz A, Stam WT, Tice H, Bornberg-Bauer E, Green PJ, Pearson GA, Procaccini G, Duarte CM, Schmutz J, Reusch TBH, Van de Peer Y (2016) The genome of the seagrass Zostera marina reveals angiosperm adaptation to the sea. Nature 530: 331-335. doi: 10.1038/nature16548

53. Pérez M, Invers O, Ruiz JM, Frederiksen MS, Holmer M (2007) Physiological responses of the seagrass Posidonia oceanica to elevated organic matter content in sediments: An experimental assessment. Journal of Experimental Marine Biology and Ecology 344: 149-160. doi: https://doi.org/10.1016/j.jembe.2006.12.020

54. Peyer SM, Maricle BR, Young DR (2020) Effect of sulfide and the role of root mass on metabolic fluxes in the seagrass Zostera marina. Environmental and Experimental Botany 180: 104267. doi: https://doi.org/10.1016/j.envexpbot.2020.104267

55. Pirc H, Wollenweber B (1988) Seasonal changes in nitrogen, free amino acids, and C/N ratio in Mediterranean seagrasses. Mar Ecol 9: 167-179

56. Platt T, Gallegos C, Harrison W (1980) Photoinhibition of photosynthesis in natural assemblages of marine phytoplankton. J Mar Res 38: 687-701

57. Pregnall A (2004) Effects of aerobic versus anoxic conditions on glutamine synthetase activity in eelgrass (Zostera marina) roots: regulation of ammonium assimilation potential. J Exp Mar Biol Ecol 311: 11-24

58. Ralph PJ, Gademann R (2005) Rapid light curves: A powerful tool to assess photosynthetic activity. Aquat Bot 82: 222-237

59. Ralph PJ, Gademann R, Dennison WC (1998) In situ seagrass photosynthesis measured using a submersible, pulse-amplitude modulated fluorometer. Mar Biol 132: 367-373

60. Rowley DC, Hansen MS, Rhodes D, Sotriffer CA, Ni H, McCammon JA, Bushman FD, Fenical W (2002) Thalassiolins A-C: new marine-derived inhibitors of HIV cDNA integrase. Bioorganic \& medicinal chemistry 10: 3619-3625

61. Schwarz AM, Bj rk M, Buluda T, Mtolera M, Beer S (2000) Photosynthetic utilisation of carbon and light by two tropical seagrass species as measured in situ. Mar Biol 137: 755-761

62. Smart JWBM (1986) Sediment-related mechanisms of growth limitation in submersed macrophytes. Ecology 67: 1328-1340

63. Szabados L, Savoure A (2010) Proline: a multifunctional amino acid. Trends Plant Sci 15: 89-97

64. Trantas EA, Koffas MAG, Xu P, Ververidis F (2015) When plants produce not enough or at all: metabolic engineering of flavonoids in microbial hosts. Front Plant Sci 6. doi: 10.3389/fpls.2015.00007

65. Tsakogiannis A, Manousaki T, Anagnostopoulou V, Stavroulaki M, Apostolaki ET (2020) The Importance of Genomics for Deciphering the Invasion Success of the Seagrass Halophila stipulacea in the Changing Mediterranean Sea. Diversity 12: 263

66. van Katwijk MM, Wijgergangs LJM (2004) Effects of locally varying exposure, sediment type and low-tide water cover on Zostera marina recruitment from seed. Aquat Bot 80: 1-12. doi: https://doi.org/10.1016/j.aquabot.2004.04.003

67. Waterman PG, Ross JA, Mckey DB (1984) Factors affecting levels of some phenolic compounds, digestibility, and nitrogen content of the mature leaves of Barteria fistulosa (Passifloraceae). J Chem Ecol 10: 387-401

68. Waycott M, Duarte CM, Carruthers TJ, Orth RJ, Dennison WC, Olyarnik S, Calladine A, Fourqurean JW, Heck KL, Hughes AR (2009) Accelerating loss of seagrasses across the globe threatens coastal ecosystems. Proc Natl Acad Sci USA 106: 12377-12381. doi: doi: 10.1073/pnas.0905620106

69. Yiu J-C, Tseng M-J, Liu C-W (2011) Exogenous catechin increases antioxidant enzyme activity and promotes flooding tolerance in tomato (Solanum lycopersicum). Plant Soil 344: 213-225

70. Yordanova RY, Popova LP (2007) Flooding-induced changes in photosynthesis and oxidative status in maize plants. Acta Physiol Plant 29: 535-541

71. Zhang Q, Liu J, Zhang P-D, Liu Y-S, Xu Q (2015) Effect of silt and clay percentage in sediment on the survival and growth of eelgrass Zostera marina: Transplantation experiment in Swan Lake on the eastern coast of Shandong Peninsula, China. Aquat Bot 122: 15-19. doi: https://doi.org/10.1016/j.aquabot.2015.01.001

72. Zidorn C (2016) Secondary metabolites of seagrasses (Alismatales and Potamogetonales; Alismatidae): Chemical diversity, bioactivity, and ecological function. Phytochemistry 124: 5-28

\section{Figures}

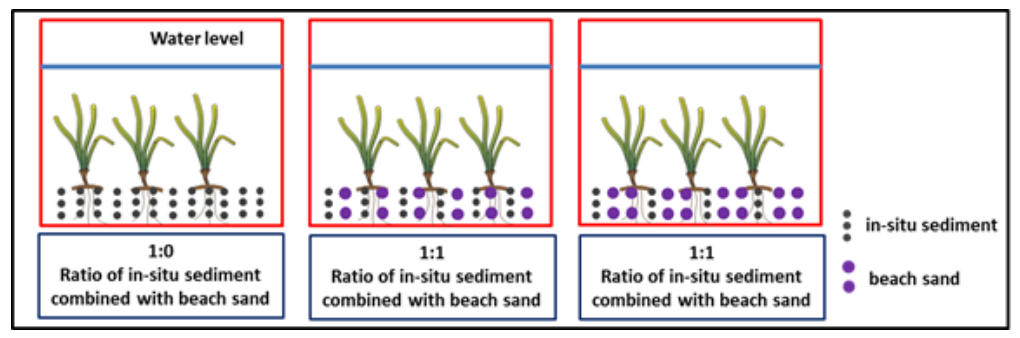

Figure 1 
Experimental set-up of the laboratory treatment. 1:0, the in-situ sediment without combining with coarse beach sand was added in the tank; $1: 1$, the combination of half in-situ sediment and half coarse beach sand was added in the tank; $1: 2$, the combination of $1 / 3$ in-situ sediment and $2 / 3$ coarse beach sand was added in the tank.
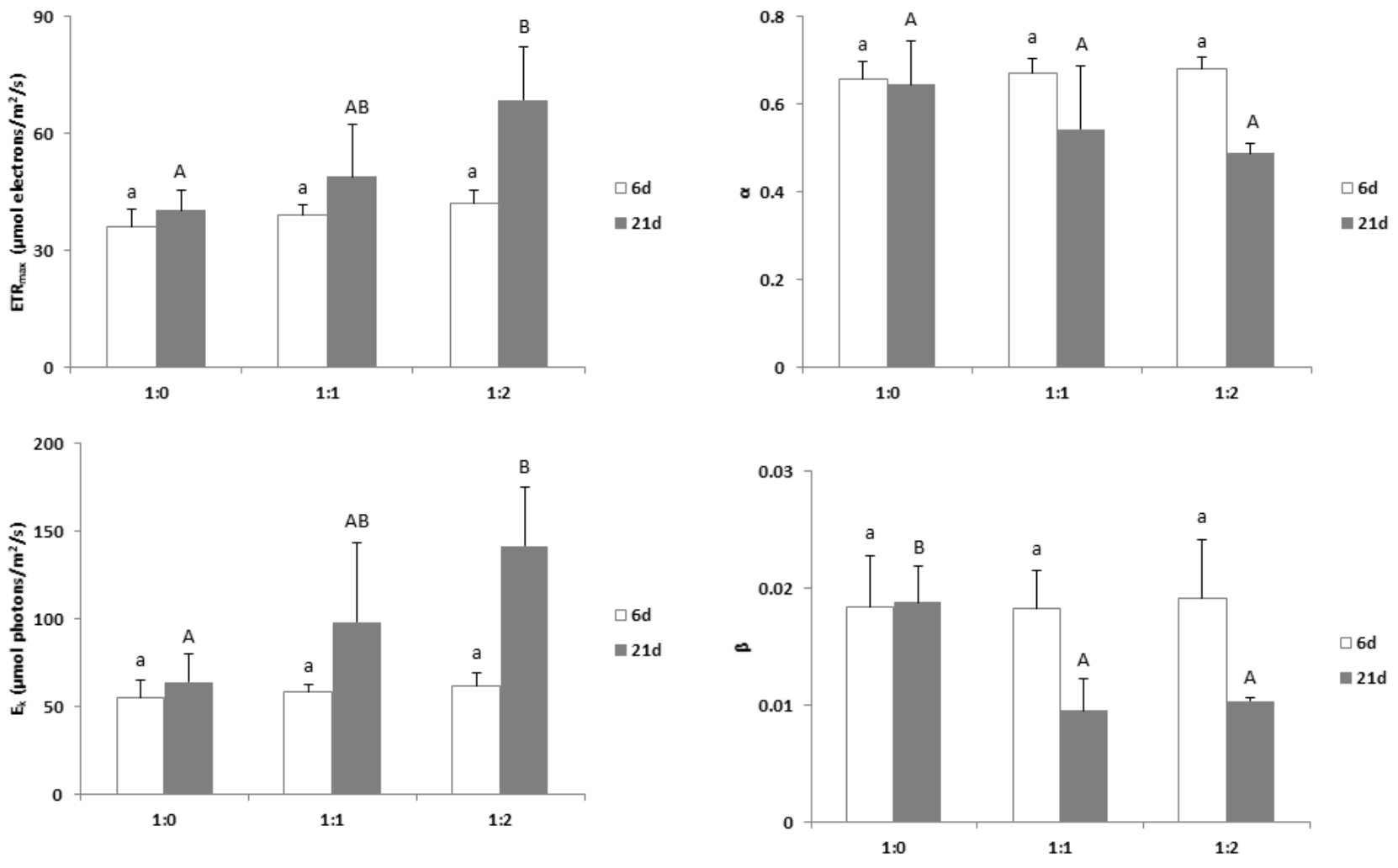

\section{Figure 2}

Photosynthetic parameters of Thalassia hemprichii derived from rapid light curve cultured in different sediment types. The lowercase and uppercase letters indicate significant difference at day 6 and day 21, respectively $(P<0.05) .1: 0$, the in-situ sediment without combining with coarse beach sand was added in the tank; $1: 1$, the combination of half in-situ sediment and half coarse beach sand was added in the tank; $1: 2$, the combination of $1 / 3$ in-situ sediment and $2 / 3$ coarse beach sand was added in the tank.
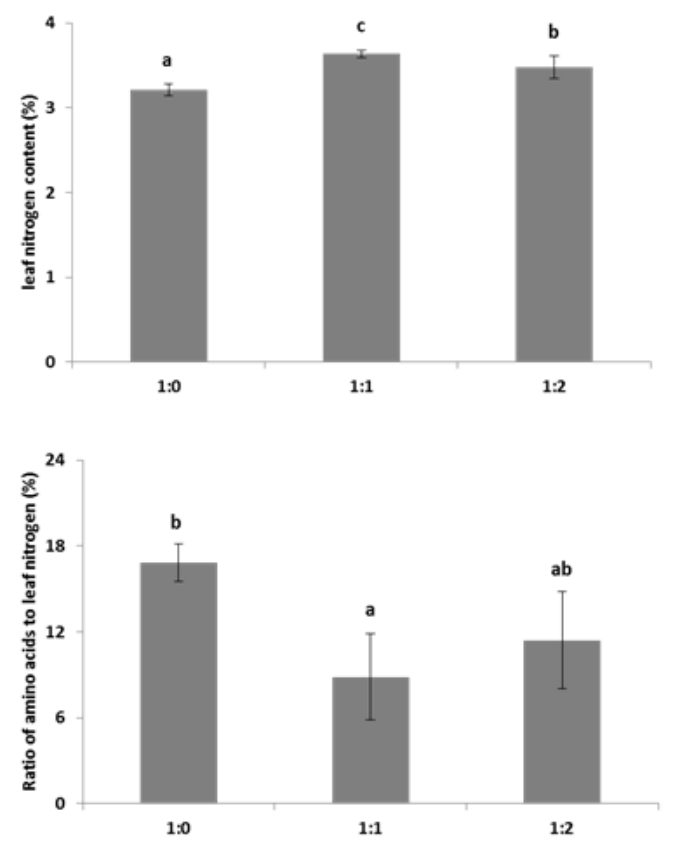

Figure 3 
Effect of sediment type on leaf nitrogen and the ratio of amino acids to nitrogen in seagrass Thalassia hemprichii. Different letters on column indicate significant difference $(P<0.05)$. 1:0, the in-situ sediment without combining with coarse beach sand was added in the tank; 1:1, the combination of half in-situ sediment and half coarse beach sand was added in the tank; $1: 2$, the combination of $1 / 3$ in-situ sediment and $2 / 3$ coarse beach sand was added in the tank.
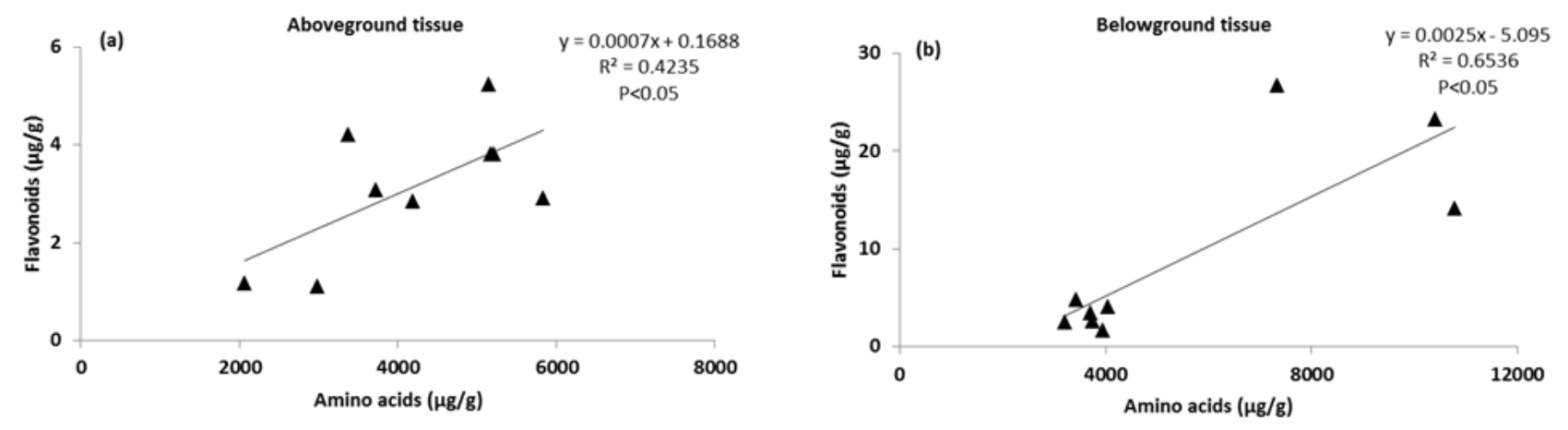

Figure 4

Relationship of amino acids and flavonoids in the aboveground (a) and belowground (b) tissues of Thalassia hemprichii under different sediment types.

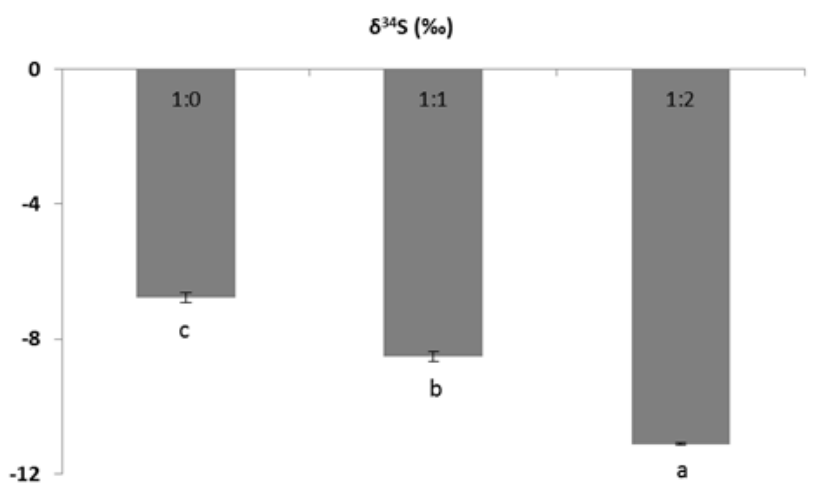

Figure 5

Effect of sediment type on the sulfur stable isotope (834S) in the belowground tissue of seagrass Thalassia hemprichii. Different letters on column indicate significant difference $(P<0.05)$. 1:0, the in-situ sediment without combining with coarse beach sand was added in the tank; 1:1, the combination of half in-situ sediment and half coarse beach sand was added in the tank; $1: 2$, the combination of 1/3 in-situ sediment and $2 / 3$ coarse beach sand was added in the tank.

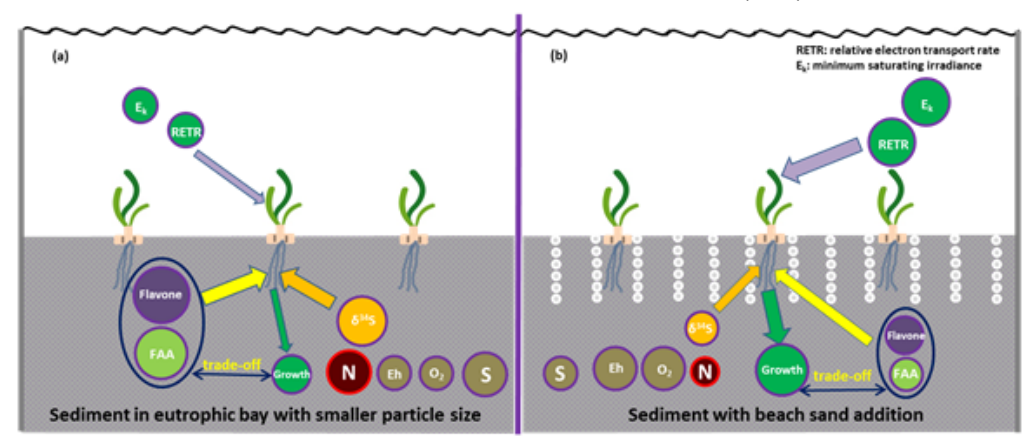

\section{Figure 6}

Schematic pictures of the effect of sediment on the photosynthesis, stable isotope sulfur, FAA (free amino acid) and flavone of seagrasses. Fig. 6a indicated that seagrass growing in sediment in eutrophic bay with lower particle size, showed smaller RTER (relative electron transport rate) and Ek (the minimum saturating irradiance), while higher FAA and Flavone accumulated in the belowground tissue to counteract anoxic stress. Fig. $6 \mathrm{~b}$ indicated that beach sand addition indirectly enhanced RETR and Ek by improving the growth condition for seagrass with lower flavone and FAA.

\section{Supplementary Files}

This is a list of supplementary files associated with this preprint. Click to download.

- supplementmaterialR1.docx 